\title{
Farmed fish as a source of dioxins and PCBs for Polish consumers
}

\author{
Szczepan Mikołajczyk ${ }^{\bowtie}$, Małgorzata Warenik-Bany, \\ Sebastian Maszewski, Marek Pajurek \\ Department of Radiobiology, \\ National Veterinary Research Institute, 24-100 Puławy, Poland \\ szczepan.mikolajczyk@piwet.pulawy.pl
}

Received: February 2, 2020 Accepted: August 11, 2020

\begin{abstract}
Introduction: This paper reports polychlorinated dibenzo-p-dioxin (PCDD), polychlorinated dibenzofuran (PCDF), and polychlorinated biphenyl (PCB) concentrations in fish collected from Polish and Vietnamese farms and the related risk for consumers. Material and Methods: Altogether, 160 samples were analysed using an isotope dilution technique with highresolution gas chromatography coupled with high-resolution mass spectrometry (HRGC-HRMS). To characterise the potential health risk associated with PCDD/F and dioxin-like polychlorinated biphenyl (DL-PCB) intake, doses ingested in two $100 \mathrm{~g}$ portions of fish by adults and children were calculated and expressed as the percentage of the tolerable weekly intake (TWI) newly established by the EFSA in November 2018 at 2 pg WHO-TEQ kg ${ }^{-1}$ b.w. Results: Generally, levels in fish muscles were low in relation to maximum limits (4), being in the range of 0.02-3.98 pg WHO-TEQ $\mathrm{g}^{-1}$ wet weight (w.w.) for PCDD/F/DL-PCBs and 0.05-24.94 $\mathrm{ng} \mathrm{g}^{-1}$ w.w. for NDL-PCBs. The highest concentration was found in eel muscles. The least polluted were pangas and zanders and the levels were at the limits of quantification. Consumption of two portions of fish per week results in intakes of 9$866 \%$ TWI by children and 4-286\% TWI by adults. Conclusion: Frequent consumption of some species (for example eel and bream) can pose a health risk to vulnerable consumers and especially children and pregnant women.
\end{abstract}

Keywords: farmed fish, dioxins, PCBs, risk to consumers.

\section{Introduction}

As a result of the Belgian crisis in 1999, during which food contaminated by polychlorinated dibenzo-pdioxins (PCDDs), polychlorinated dibenzofurans (PCDFs) and dioxin-like polychlorinated biphenyls (DL-PCBs) was found in that country and almost all over Europe, the European Union adopted a strategy to reduce the levels of these toxic compounds in the environment and food and to reduce consumer exposure to them (3). Thus, in 2001-2002 a level representing the safe weekly human dose of PCDDs, PCDFs, and DLPCBs, designated the tolerable weekly intake (TWI), was established at $14 \mathrm{pg}$ WHO-(TEQ) $\mathrm{kg}^{-1}$ b.w., as was the provisional tolerable monthly intake (PTMI) at $70 \mathrm{pg}$ WHO-TEQ $\mathrm{kg}^{-1}$ b.w. Since that time, new evidence of dioxins' toxicity has come to light and therefore in November 2018 the European Food Safety Authority decided to reduce the TWI by a factor of seven (7). Studies show that food, including fish, is a major source $(>90 \%)$ of dioxins and PCBs for humans (7). Dietary recommendations include eating fish at least twice a week because of the valuable nutrients it contains (11). The most important are long-chain polyunsaturated fatty acids, macro- and trace elements, fat-soluble vitamins (mainly $\mathrm{D}_{3}$ ), amino acids, and easily absorbed proteins. Unfortunately, fish living in a polluted environment or sustained by contaminated feeds may accumulate toxic compounds, which include PCDD/Fs and PCBs. The aim of the study was to assess the actual state of farmed fish contamination by PCDD/F/DL-PCBs and the related risk for fish consumers in relation to the newly established TWI.

\section{Material and Methods}

Sampling and sample collection. The sampling procedure was in accordance with the provisions of regulations 252/2012/EC, 589/2014/EC and 644/2017/EC. 
Altogether 160 samples, including eel, rainbow trout, bream, sturgeon, carp, and zander were collected between 2010-2019 from Polish fish farms by the State Veterinary Inspectorate, and the 10 pangas included were from Vietnam (Table 1).

Sample preparation, extraction, and purification. The analytical method has been described in detail in previous paper (13). Briefly, freeze dried fish muscles were spiked with a ${ }^{13} \mathrm{C}_{12}$-internal labelled standard and extracted using accelerated solvent extraction. Purification and fractionation were carried out using multilayer acidified silica, Florisil, and active carbon columns. Three separate fractions were obtained: one for PCDD/Fs and the other two for DL-PCBs and NDL-PCBs.

Reagents, chemicals, and analytes. All of the organic solvents were of suitable purity for the residue analysis. Dichloromethane, n-hexane and toluene were supplied by LGC Standards (Wesel, Germany). Silica gel was purchased from Fluka (Buchs, Switzerland) and sodium sulphate and 98\% ACS grade sulphuric acid were obtained from Merck (Darmstadt, Germany). Helium (purity 99.9999\%) and nitrogen (99.999\%) were sourced from Messer (Gumpoldskirchen, Austria). Diatomaceous earth was procured from Restek (Bellefonte, PA, USA). Seven 2,3,7,8-substituted PCDDs $(2,3,7,8-T C D D, 1,2,3,7,8-P e C D D, 1,2,3,4,7,8-$ HxCDD， 1,2,3,6,7,8-HxCDD， 1,2,3,7,8,9-HxCDD, $1,2,3,4,6,7,8-\mathrm{HpCDD}$, and OCDD), ten 2,3,7,8substituted PCDFs $(2,3,7,8-\mathrm{TCDF}, 1,2,3,7,8-\mathrm{PeCDF}$, 2,3,4,7,8-PeCDF, 1,2,3,4,7,8-HxCDF, 1,2,3,6,7,8$\mathrm{HxCDF} ， 2,3,4,6,7,8-\mathrm{HxCDF}, \quad 1,2,3,7,8,9-\mathrm{HxCDF}$, 1,2,3,4,6,7,8-HpCDF, 1,2,3,4,7,8,9-HpCDF, and OCDF), twelve DL-PCBs (PCB 77, PCB 81, PCB 126, PCB 169, PCB 105, PCB 114, PCB 118, PCB 123, PCB 156, PCB 157, PCB 167, and PCB 189) and six NDLPCBs (PCB 28, PCB 52, PCB 101, PCB 138, PCB 153, and $\mathrm{PCB} 180)$ were analysed. All native standards and their ${ }^{13} \mathrm{C}_{12}$ homologues were purchased from the Cambridge Isotope Laboratory (Andover, USA) and Wellington Laboratories Inc. (Guelph, Canada).

Standards and reference materials. The concentrations of the set of ${ }^{13} \mathrm{C}_{12}$-labelled analogues of the analysed congeners used as internal standards were $25 \mathrm{pg} \mathrm{mL}^{-1}$ for PCDD/Fs, $400 \mathrm{pg} \mathrm{mL}^{-1}$ for DL-PCBs

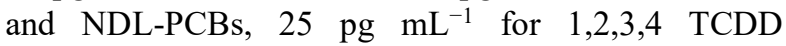
(recovery), and $400 \mathrm{pg} \mathrm{mL}^{-1}$ for PCB (recovery). The calibration curve held a range of 7 points for PCDD/Fs (0.05 to $\left.5 \mathrm{pg} \mu \mathrm{L}^{-1}\right), 6$ points for DL-PCBs $\left(0.02\right.$ to $\left.40 \mathrm{pg}_{\mu} \mathrm{L}^{-1}\right)$, and 5 points for NDL-PCBs (1 to $500 \mathrm{pg} \mu \mathrm{L}^{-1}$ ). T-0645-fish oil (FAPAS, York, UK) was used as a reference material.

Instrumental analysis. Detection was carried out using a high-resolution gas chromatograph system coupled with a high resolution mass spectrometer (HRGC-HRMS): a Trace GC Ultra gas chromatograph, TriPlus autosampler, and DFS dual-focusing mass spectrometer (Thermo Scientific, Bremen, Germany).

A DB-5 MS fused silica capillary column $(60 \mathrm{~m} \times 0.25 \mathrm{~mm} \times 0.1 \mathrm{~mm})$ was used with the splitless injection mode of $2 \mu \mathrm{L}$ and helium as a carrier gas. The TEQ values were calculated using the WHO toxic equivalency factors established by Van den Berg (22). WHO-TEQs were expressed as upper-bound concentrations (all values of the specific PCDD/F and DL-PCB congeners below the limit of quantitation (LOQ) were equal to their respective LOQ). The LOQs for PCDD/F and DL-PCB were isomer-dependent and varied from 0.002 to $2.71 \mathrm{pg} \mathrm{g}^{-1}$ w.w. and for NDL-PCBs their spread was from 0.0004 to $0.022 \mathrm{ng} \mathrm{g}^{-1}$ w.w. The recoveries of the internal standards ranged between $60 \%$ and $120 \%$. Positive electron ionisation (EI) operating in SIM mode at a resolution of 10,000 was employed.

Quality assurance and control. Quality assurance and control (QA/QC) were achieved through analysis of blank samples and reference material. The relative standard deviations (RSD) for all of the compounds were $15 \%$ for both the replicates and the reference materials. The mass spectrometer conditions were checked daily for appropriate 10,000 resolution and sufficient tuning by response to the tuning compound (FC43perfluorotributylamine) before the sample analysis. The method performance was verified by successful participation in the proficiency testing (PT study) organised by the European Union Reference Laboratory for halogenated persistent organic pollutants (POPs) in Feed and Food (Freiburg, Germany).

Statistical analysis. For analysis of results descriptive statistics parameters were used: average, standard deviation (SD), and concentration range. Shapiro-Wilk testing was used to verify normal distribution of the data. To compare the differences between individual experimental groups, the KruskalWallis non parametric test (at $\mathrm{P} \leq 0.05$ ) was applied.

Risk for consumers. Doses ingested with fish were expressed as the percentage of TWI (2 pg WHO-TEQ $\mathrm{kg}^{-1} \quad$ b.w.) to characterise the potential health risk associated with dioxins and DL-PCBs intake. The calculations were performed for an adult of $70 \mathrm{~kg}$ and a child of $23.1 \mathrm{~kg}$ (8). A single portion of fish (100 g) consumed twice a week (according to recommendations) was used as the dietary intake (11). This calculation does not take into account other food consumed which can also be a source of PCDD/F/DL-PCBs.

\section{Results}

Eels accumulated statistically significantly more dioxins and PCBs than the other species (Table 2). Nevertheless, eel muscles contained low levels in relation to the maximum limits (about 30\% for the sum of dioxins and DL-PCBs and 13\% for NDL-PCBs) (Table 2). Average concentrations of PCDD/F/DL-PCB in the less-polluted carp, trout, sturgeon, and bream were between $5 \%$ and $11 \%$ and NDL-PCB between $1 \%$ and $3 \%$ of the maximum levels. The least-polluted panga and zander accumulated PCDD/F/DL-PCB at the level of the LOQ and the mean concentration ranged from $0.6 \%$ to $0.8 \%$; NDL-PCB concentration ranged from $0.08 \%$ to 
$0.6 \%$ of the maximum limits. Concentrations of PCDD/F/DL-PCB were higher in species of which the muscles contained more fat (Table 2). The exception was bream, which was on average half as fatty as sturgeon, but accumulated over 50\% more PCDD/F/DLPCBs.

Fig. 1 compares the percentage share of PCDD, PCDF, and DL-PCB congeners to the total toxicity (expressed in WHO-TEQ) of freshwater fish muscle. Bioaccumulations were species-dependent. DL-PCBs contributed the most to the total toxicity, from $52 \%$ in bream to over $76 \%$ in eel muscles. Dioxins contributed less than DL-PCBs but more than furans (from $15 \%$ in eels to $26 \%$ in trout) (Fig. 1). An exception to this trend was bream, because in their muscles furans accounted for $27 \%$ and dioxins for $21 \%$. These differences may result from species specificity and environmental pollution or diet. As only one congener from the group of furans was detected in zander and panga muscles, this muscle tissue was not presented in Fig. 1.

\section{Risk for consumers}

The estimated dioxin and DL-PCB intake ranges from $9 \%$ to $866 \%$ TWI for children and from $4 \%$ to $286 \%$ TWI for adults (Table 3). Levels of dioxins and DL-PCBs found in panga and zander are low, not exceeding the LOQ level.

Table 1. Sampling points

\begin{tabular}{lll}
\hline Species & Sampling point (province, country) & Number of samples \\
\hline eel & $\begin{array}{l}\text { Warmian-Masuria, Greater Poland, Kuyavia-Pomerania, Pomerania, West } \\
\text { Pomerania }\end{array}$ \\
& $\begin{array}{l}\text { Lower Silesia, Lublin, Lubuskie, Lesser Poland, Masovia, Opole, Podlasie, } \\
\text { rainbow trout }\end{array}$ & Silesia, Warmia-Masuria \\
bream & West Pomerania, Lesser Poland, Warmia-Masuria, Greater Poland \\
& Lower Silesia, Lublin, Lubuskie, Lesser Poland, Masovia, Opole, Podlasie, \\
sturgeon & Silesian, Warmia-Masuria \\
& Lower Silesia, Lublin, Lubuskie, Lesser Poland, Masovia, Opole, Podlasie, \\
carp & Silesian, Warmia-Masuria \\
& Subcarpathia, Lublin, Warmia-Masuria \\
zander & Vietnam
\end{tabular}

Table 2. PCDD/F, DL-PCB and NDL-PCB ( $x \pm \mathrm{SD}$, range)

\begin{tabular}{|c|c|c|c|c|c|c|c|}
\hline \multirow{2}{*}{ Species } & \multirow{2}{*}{$\begin{array}{l}\text { Fat } \\
\%\end{array}$} & \multicolumn{5}{|c|}{ pg WHO-TEQg ${ }^{-1}$ w.w. } & \multirow{2}{*}{$\frac{\text { ng g }^{-1} \text { w.w. }}{\text { NDL-PCB }}$} \\
\hline & & PCDD & PCDF & $\mathrm{PCDD} / \mathrm{F}$ & DL-PCB & $\begin{array}{l}\mathrm{PCDD} / \mathrm{F} / \mathrm{DL}- \\
\mathrm{PCB}\end{array}$ & \\
\hline \multirow{2}{*}{ eel } & \multirow{2}{*}{$18.63 \pm 6.81$} & $0.30 \pm 0.14$ & $0.18 \pm 0.07$ & $0.48 \pm 0.21$ & $1.52 \pm 0.68$ & $2.00 \pm 0.85$ & $9.98 \pm 6.43$ \\
\hline & & $0.17-0.64$ & $0.10-0.38$ & $0.27-1.02$ & $0.71-2.97$ & $1.03-3.98$ & $2.83-24.94$ \\
\hline \multirow{2}{*}{ bream } & \multirow{2}{*}{$4.12 \pm 0.8$} & $0.15 \pm 0.07$ & $0.19 \pm 0.1$ & $0.33 \pm 0.14$ & $0.37 \pm 0.18$ & $0.70 \pm 0.23$ & $1.53 \pm 0.49$ \\
\hline & & $0.09-0.26$ & $0.06-0.34$ & $0.20-0.58$ & $0.20-0.67$ & $0.45-1.01$ & $0.60-1.96$ \\
\hline \multirow{2}{*}{ sturgeon } & \multirow{2}{*}{$8.01 \pm 4.16$} & $0.10 \pm 0.03$ & $0.08 \pm 0.03$ & $0.18 \pm 0.03$ & $0.27 \pm 0.22$ & $0.45 \pm 0.24$ & $1.93 \pm 0.55$ \\
\hline & & $0.09-0.14$ & $0.05-0.13$ & $0.13-0.21$ & $0.17-0.67$ & $0.31-0.88$ & $1.16-2.4$ \\
\hline \multirow{2}{*}{ carp } & \multirow{2}{*}{$6.01 \pm 8.36$} & $0.09 \pm 0.02$ & $0.05 \pm 0.03$ & $0.14 \pm 0.3$ & $0.19 \pm 0.4$ & $0.33 \pm 0.72$ & $0.50 \pm 1.67$ \\
\hline & & $0.02-0.15$ & $0.03-0.15$ & $0.02-1.75$ & $0.01-2.6$ & $0.03-4.35$ & $0.11-12.97$ \\
\hline \multirow{2}{*}{$\begin{array}{l}\text { rainbow } \\
\text { trout }\end{array}$} & \multirow{2}{*}{$5.51 \pm 1.71$} & $0.09 \pm 0.0$ & $0.05 \pm 0.01$ & $0.14 \pm 0.01$ & $0.20 \pm 0.08$ & $0.32 \pm 0.08$ & $1.80 \pm 1.34$ \\
\hline & & $0.09-0.09$ & $0.04-0.07$ & $0.03-0.32$ & $0.02-0.33$ & $0.05-0.47$ & $0.05-8.39$ \\
\hline \multirow[t]{2}{*}{ panga } & \multirow{2}{*}{$0.93 \pm 0.41$} & $0.01 \pm 0.0$ & $0.01 \pm 0.0$ & $0.01 \pm 0.0$ & $0.01 \pm 0.0$ & $0.02 \pm 0.0$ & $0.06 \pm 0.01$ \\
\hline & & $0.01-0.01$ & $0.01-0.01$ & $0.01-0.02$ & $0.01-0.01$ & $0.02-0.02$ & $0.05-0.08$ \\
\hline \multirow[t]{2}{*}{ zander } & \multirow{2}{*}{$0.34 \pm 0.05$} & $0.01 \pm 0.0$ & $0.01 \pm 0.0$ & $0.01 \pm 0.0$ & $0.01 \pm 0.0$ & $0.03 \pm 0.01$ & $0.50 \pm 0.67$ \\
\hline & & $0.01-0.01$ & $0.01-0.01$ & $0.01-0.01$ & $0.01-0.02$ & $0.02-0.04$ & $0.11-2.97$ \\
\hline \multicolumn{2}{|c|}{ Maximum levels (reference 4) } & - & - & 3.5 & - & 6.5 & 75 \\
\hline
\end{tabular}




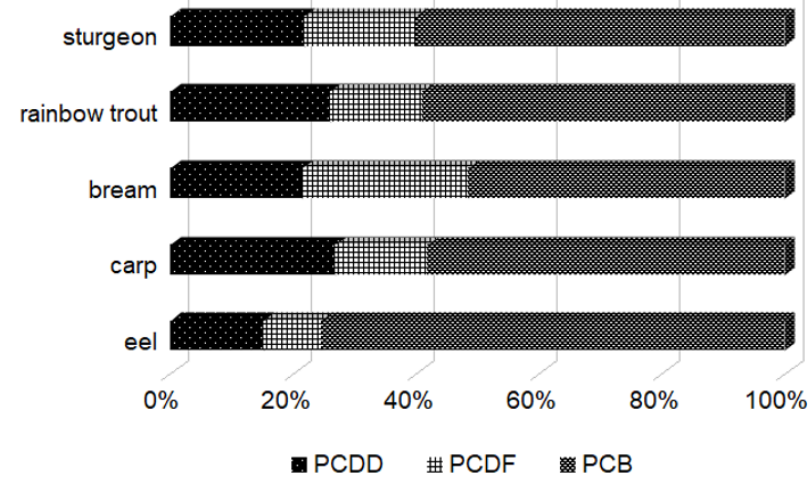

Fig. 1. Percentage share of PCDD, PCDF and DL-PCB in the total toxicity

Table 3. Estimated intake of PCDD/F and DL-PCB with $200 \mathrm{~g}$ of fish, expressed as \% of TWI

\begin{tabular}{lll}
\hline Fish species & $\begin{array}{l}\text { Children } \\
\text { \% TWI }\end{array}$ & $\begin{array}{l}\text { Adult } \\
\% \text { TWI }\end{array}$ \\
\hline eel & 866 & 286 \\
bream & 303 & 100 \\
sturgeon & 195 & 64 \\
carp & 143 & 47 \\
rainbow trout & 139 & 46 \\
panga & 9 & 3 \\
zander & 13 & 4 \\
\hline
\end{tabular}

Taking into account that the results are expressed according to the upper-bound concept, which requires using the limit of quantification for the contribution of each non-quantified congener, the risk assessment results are clearly overestimated. Therefore, panga and zander muscle tissue can be regarded as practically "PCDD/F/DL-PCBs-free" and its consumption as having no significant impact on human health. However, regular consumption of some species (eel and bream) can pose a health risk and especially for vulnerable groups of consumers who frequently consume these species.

\section{Discussion}

Fish farming can be carried out either in open tanks or in closed buildings with a water recirculation system, without contact with the external environment. The closed water recirculation system and isolation from the external environment is designed to eliminate diseases, but also can minimise dioxin and PCB contamination of fish. The quality of the feeds used in the feeding system is becoming important for the breeding process. Feed in Poland is subjected to annual control under the national feed quality monitoring programme (14). Low levels of dioxins and PCBs determined in farmed fish as well as the conducted feed control studies indicate that feed quality is good, and it does not represent a significant source of these contaminants for fish (14).
In the literature there are many papers devoted to farmed marine fish, mainly salmon. In salmon reared in northern Europe, North America, and Chile, levels of PCDD/F/DL-PCB were higher than those in free-living fish, which could indicate a significant impact of feed materials on fish contamination. Salmon reared in Europe were more contaminated than those from North and South America, with the highest levels having been found in salmon reared in Scotland and the Faroe Islands (10). Fish feed technology is based on the use of fish oil and fishmeal (9), both of which may contain dioxins and PCBs (15). Therefore, measures have been taken to replace fish oil with vegetable oil $(12,17)$. The result has been a decrease in the levels of dioxins and PCBs in Norwegian Atlantic salmon and those of North America and eastern Canada $(12,17)$. An alternative method of fishmeal decontamination is extraction of dioxins and PCBs with hexane. This method was positively assessed by the EFSA. The process allows for reduction of about $70 \%$ of $\mathrm{PCDD} / \mathrm{F} / \mathrm{DL}-\mathrm{PCBs}$ and about $60 \%$ of NDL$\mathrm{PCBs}$ and meets the requirements of the Regulation laying down criteria for the acceptability of detoxification processes for products intended for animal feed (5).

In a study conducted in Greece, PCDD/F concentrations in freshwater trout were about $7 \%$ lower, while DL-PCB concentrations were $65 \%$ higher than in this study (6). Low contamination of carp by NDL-PCBs (1.4 ng/g w.w.) and perch (1.14 ng/g w.w.) from farms in the Lorraine area in France was reported by Thomas et al. (21). Also low levels $(5.4 \mathrm{ng} / \mathrm{g} \mathrm{w} . \mathrm{w}$. for 36 congeners) were found in rainbow trout from Canada (16) and trout from Denmark, Italy, and Turkey (3.48 ng/g w.w. for 7 congeners) (23). In the current study, farmed eels showed levels even several times lower than those of free-living counterparts from the Vistula delta area (20). German data also confirm higher contamination of free-living eels from the Elbe and its two tributaries the Mulde and Sale (18). Generally, the levels of contaminants in the farmed fish were similar to those in other countries.

Concentrations of PCDD/F/DL-PCB are generally higher in species of which the muscles contain more fat. In our studies, bream was an exception, because its muscle was on average twice as lean as that of sturgeon, but accumulated over 50\% more PCDD/F/DL-PCBs. This may be due to the type of feeding and diet, which consists of sucking of bottom sediments and filtering nutrients from them. Therefore, sediment contamination may have a greater impact on the levels of dioxins, furans and PCBs compared to other species.

The latest data provided by EFSA show that fish consumption results in a dioxin and DL-PCB intake of up to $26.3 \%$ and $56 \%$ for infants and adults, respectively (7). That is why the TWI value (14 pg WHO-TEQ $\mathrm{kg}^{-1}$ b.w. per week) established in 2001 was exceeded for part of the European population and in particular for children $(1,2)$. It is, therefore, important from the point of view of food safety to find out how decreasing the TWI to 2 pg WHO-TEQ $\mathrm{kg}^{-1}$ b.w. will influence the risk 
assessment results. The average, total fish and fish product monthly consumption in Poland is estimated at $0.29 \mathrm{~kg}$ per person (19). Such values suggest that the dietary intake of dioxins with fish and fishery products of Polish consumers is expected to be low. Taking into account the low national fish consumption, it seems that the problem does not apply to the general population. Occasionally, elevated dioxin intakes above TWI are not necessarily related to health risk because of uncertainty factors embedded in these toxicological reference values. However, vulnerable sub-populations that frequently consume eel, bream or sturgeon may be at elevated health risk due to potential consequences of chronic exposure to dioxins and DL-PCBs.

Conflict of Interests Statement: The authors declare that there is no conflict of interests regarding the publication of this article.

Financial Disclosure statement: This study was financed by the Polish Ministry of Agriculture and Rural Development as a part of the Multiannual Programme "Control of the presence of prohibited substances in food of animal origin and undesirable substances in animal feed".

Animal Right Statement: Not applicable.

\section{References}

1. Bergkvist C., Öberg M., Appelgren W., Becker M., Aune E.H., Ankarberg M., Berglund M., Håkansson H.: Exposure to dioxinlike pollutants via different food commodities in Swedish children and young adults. Food Chem Toxicol 2008, 46, 3360-3367.

2. Bilau M., Matthys C., Baeyens W., Bruckers L., De Backer G., Den Hond E.: Dietary exposure to dioxin-like compounds in three age groups: results from the Flemish environment and health study. Chemosphere 2008, 70, 584-92.

3. Commission the European Communities: COM (2001) 593/F1, Communication from the Commission to the Council, The European Parliament and the Economic and Social Committee: Community Strategy for Dioxins, Furans and Polychlorinated Biphenyls, 2001. OJ C 322/44, 17/11/2001, 2-18.

4. Commission the European Communities: Commission Regulation (EU) 1259/2011 of 2 December 2011 amending Regulation (EC) No 1881/2006 as regards maximum levels for dioxins, dioxin-like PCBs and non dioxin-like PCBs in foodstuffs. OJ L 320/54, 2/12/2011, 18-23.

5. Commission the European Communities: Commission Regulation (EU) 2015/786 defining acceptability criteria for detoxification processes applied to products intended for animal feed 2015. OJ L 125/58, 10-14.

6. Costopoulou D., Vassiliadou I., Leondiadis L.: PCDDs, PCDFs, and PCBs in farmed fish produced in Greece: Levels and human population exposure assessment. Chemosphere 2016, 146, 511-518.

7. EFSA Panel on Contaminants in the Food Chain: Scientific Opinion. Risk for animal and human health related to the presence of dioxins and dioxin-like PCBs in feed and food. EFSA J 2018, 16,5333 .
8. EFSA Scientific Committee: Guidance on selected default values to be used by the EFSA Scientific Committee, Scientific Panels, and Units in the absence of actual measured data. EFSA J 2012, $10,2579$.

9. Ginés R., Camacho M., Henríquez-Hernández L.A., Izquierdo M., Boada L.D., Montero D., Robaina L., Zumbado M., Luzardo O.P.: Reduction of persistent and semi-persistent organic pollutants in fillets of farmed European seabass (Dicentrarchus labrax) fed low fish oil diets. Sci Total Environ 2018, 643, 1239-1247.

10. Hites R.A., Foran J.A., Carpenter D.O., Hamilton M.C., Knuth B.A., Schwager S.J.: Global assessment of organic contaminants in farmed salmon. Science 2004, 303, 226-229.

11. Jarosz M.: Normy żywienia dla populacji Polski. Instytut Żywności i Żywienia, Warszawa, 2017.

12. Nøstbakken O.J., Hove H.T., Duinker A., Lundebye A.K., Berntssen M.H.G., Hannisdal R., Lunestad B.J., Maage A., Madsen L., Torstensen B.E., Julshamn K.: Contaminant levels in Norwegian farmed Atlantic salmon (Salmo salar) in the 13-year period from 1999 to 2011. Environ Int 2015, 74, 274-280.

13. Piskorska-Pliszczynska J., Lizak R., Maszewski S., Małagocki P., Wijaszka T.: Survey of persistent organochlorine contaminants (PCDD, PCDF, DL-PCB) in Baltic fish and fish meals. Bull Vet Inst Pulawy 2009, 53, 825-831.

14. Piskorska-Pliszczynska J., Małagocki P., Pajurek M.: Levels and trends of PCDD/Fs and DL-PCBs in Polish animal feeds, 2004-2017. Food Addit Contam Part A 2019, 36, 1-17.

15. Piskorska-Pliszczyńska J., Maszewski S., Mikołajczyk S., Warenik-Bany M., Góraj Ł.: Rodzaje i stężenia kongenerów dioksyn, furanów i dl-PCB w krajowych materiałach paszowych. Materiały i dodatki paszowe - aktualne wymagania Cz. I. Pasze przemysłowe. Inst Zootechn-PIB, Lublin 2011, 27-33.

16. Rawn D.F.K., Forsyth D.S., Ryan J.J., Breakell K., Verigin V., Nicolidakis H., Hayward S., Laffey P., Conacher H.B.S.: PCB, PCDD and PCDF residues in fin and non-fin fish products from the Canadian retail market 2002. Sci Total Environ 2006, 359, 101-110.

17. Shaw S.D., Brenner D., Berger M.L., Carpenter D.O., Hong C.S., Kannan K.: PCBs, PCDD/Fs, and organochlorine pesticides in farmed Atlantic salmon from Maine, Eastern Canada, and Norway, and wild salmon from Alaska. Environ Sci Technol 2006, 40, 5347-5354.

18. Stachel B., Christoph E.H., Gotz R., Herrmann T., Kruger F., Kuhn T., Lay J., Loffler J., Papke O., Reincke H., Schroter-Kermani C., Schwartz R., Steeg E., Stehr D., Uhlig S., Umlauf G.: Dioxins and dioxin-like PCBs in different fish from the river Elbe and its tributaries, Germany. J Hazard Mater 2007, 148, 199-209.

19. Statistics Poland: Statistical Yearbook of the Republic of Poland. Statistics Poland, Warsaw, 2018.

20. Szlinder-Richert J., Usydus Z., Pelczarski W.: Organochlorine pollutants in European eel (Anguilla anguilla L.) from Poland. Chemosphere 2010, 80, 93-99.

21. Thomas M., Lazartigues A., Banas D., Brun-Bellut J., Feidt C.: Organochlorine pesticides and polychlorinated biphenyls in sediments and fish from freshwater cultured fish ponds in different agricultural contexts in north-eastern France. Ecotox Environ Safe 2012, 77, 35-44.

22. Van den Berg M., Birnbaum L.S., Denison M., De Vito M., Farland W., Feeley M., Fiedler H., Håkansson H., Hanberg A., Haws L., Rose M., Safe S., Schrenk D., Tohyama C., Tritscher A., Tuomisto J., Tysklind M., Walker N., Peterson R.E.: The 2005 World Health Organization reevaluation of human and mammalian toxic equivalency factors for dioxins and dioxin-like compounds. Toxicol Sci 2006, 93, 223-241.

23. Van Leeuwen S.P.J., Van Velzen M.J.M., Swart C.P., Van Der Veen I., Traag W.A., De Boer J.: Halogenated contaminants in farmed salmon, trout, tilapia, pangasius, and shrimp. Environ Sci Technol 2009, 43, 4009-4015. 